TILTAI, 2015, 2, 47-65, ISSN 1392-3137 (Print), ISSN 2351-6569 (Online)

\title{
SOCIALIAI ATSAKINGAS VARTOJIMAS LIETUVOJE: VARTOTOJŲ CHARAKTERISTIKOS
}

\author{
Vytautas Juščius, Deimantė Dargienė \\ Klaipedos universitetas
}

\begin{abstract}
Anotacija
Straipsnyje atskleidžiamos demografinès ir socialinès charakteristikos, kuriomis pasižymi socialiai atsakingi vartotojai, bei požymiai, darantys didžiausią įtaką ketinimui ịsigyti prekę iš socialiai atsakingų įmonių. Atlikus empirinị tyrimą nustatyta, kad vartotojų socialiai atsakingą elgseną formuoja ir įtakos priimant sprendimą turi lytis, pajamų pakankamumas ir išsilavinimas. Remiantis tyrimo rezultatais nustatytas ir potencialaus socialiai atsakingų įmonių kliento profilis - tai ịvairaus amžiaus (tikètina, kad vyresnè nei 25 metų), didesnes pajamas gaunanti, išsilavinusi moteris.

PAGRINDINIAI ŽODŽIAI: socialiai atsakingas vartojimas, vartotojų demografinès ir socialinès charakteristikos.
\end{abstract}

\begin{abstract}
The article reveals demographic and social characteristics of socially responsible consumers and the attributes that have the most impact on the intention to purchase the item from socially responsible companies. Empirical study revealed that socially responsible consumer behaviour is shaped and decision-making is influenced by gender, income adequacy and education. Based on investigation results, client profile of socially responsible companies is identified - it's all ages (probably older than 25 years), higher-income, educated women.

KEY WORDS: socially responsible consumption, demographic and social characteristics of consumers.
\end{abstract}

DOI: http://dx.doi.org/10.15181/tbb.v71i2.1100

\section{Ivadas}

Intensyvios gamybos ir augančio vartojimo neigiamos pasekmès XXI amžiuje paskatino verslininkus ir suinteresuotąsias grupes aktyviau kalbėti apie socialinę atsakomybę. Neigiamos vartojimo pasekmès aplinkai ir visuomenei skatina žmones vartoti atsakingiau, atidžiau rinktis perkamas prekes. Augantys vartotojų lūkesčiai verčia įmones investuoti ị išteklius tausojančius įrenginius ir technologijas. Verslo įmonės, kurios stengiasi tausoti gamtos išteklius, siekia sumažinti žalingą gamybos poveiki gamtai, rūpinasi personalo darbo sąlygų gerinimu, moka darbuotojams adekvatų atlygi ir sulaukia pelnyto vartotojų palankumo.

Socialiai atsakingas vartojimas - tai toks vartojimas, kai ,vartotojai savo sprendimus priima vadovaudamiesi ne tik noru patenkinti asmeninius poreikius, bet ir atsižvelgdami i galimas priimamų sprendimų pasekmes aplinkai ir visuomenei“، (Ozkan, 2009, p. 947). Socialiai atsakingo vartojimo samprata apima tris aspektus: imonių poveikį vartotojų pirkimo elgsenai, vartotojų perdirbimo įpročius ir žalingų aplinkai produktų vengimo bei naudojimo mažinimą. 
Nacionalinejje įmonių socialinès atsakomybės plètros 2009-2013 m. programoje atsakingas vartojimas apibrēžiamas kaip „vartojimas, kai vartotojas renkasi prekę ar paslaugą, atsižvelgdamas ne tik ị kainą, bet ir ị prekès ar paslaugos poveikị aplinkai, socialines jos pagaminimo sąlygas, siekia išteklius taupančio vartojimo“ (Nacionalinės įmonių socialinès atsakomybės plètros 2009-2013 metų programa, 2010, p. 1). Galima teigti, kad atsakingo vartojimo sąvoka rodo vartotojų susirūpinimą etinèmis, socialinėmis ir ekologinèmis problemomis.

Tyrimo problema. Nors vartotojai vis labiau domisi įmonių socialine atsakomybe, tyrimai atskleidžia atotrūkị tarp vartotojų domèjimosi įmonių socialine atsakomybe ir šios informacijos panaudojimo priimant sprendimą pirkti ar ne tam tikrą produktą (Devinney et al., 2006; Boulstridge, Carrigan, 2000; Smith, 2007; Oberseder, et. al., 2011; Valor, 2005; Castaldo et al., 2009; D’Astous, Legendre, 2009; Bray et al., 2011; Kozar, Connell, 2013). Galima teigti, kad ši situacija yra paradoksali - nors vartotojai nori, kad įmonès vykdytų socialiai atsakingą veiklą, tačiau socialinès atsakomybės kriterijus ne visada tampa pirmaeiliu veiksniu renkantis prekes. Mokslininkai kaip tokio atotrūkio galimas priežastis įvardijo informacijos trūkumą (Boulstridge, Carrigan, 2000; Valor, 2007; Bray, Johns, 2011), menką vartotojų veiksmingumą (Cornelissen, Cojuharenco, Karelaia, 2011) ir netinkamų tyrimų metodų parinkimą (Auger, Devinney, 2007).

Vartotojų nuostatų ir požiūrių i atsakingą vartojimą tyrimų duomenys rodo, nors daugelis jų pasisako už socialiai atsakingą vartojimą ir pageidauja gauti daugiau informacijos iš ịmonių apie prekių / paslaugų gamybą, poveikio aplinkai ir visuomenei mažinimo priemones, tik nedaugelis iš tiesų socialiai atsakingai vartoja. Tikètina, kad tyrimų rezultatai atskleidžia vertybinị respondentų požiūrị ir siekị pateikti savo elgseną taip, kad ji atitiktų šias vertybines nuostatas. Tačiau vartotojų charakteristikos, kuriomis remiantis būtų galima išskirti socialiai atsakingų vartotojų segmentą Lietuvoje, nėra aiškios. Kokios vartotojų demografinès ir socialinès savybės turi įtakos prekių pasirinkimui taikant İSA kriterijų neištirta. Neaiškūs ir socialiai atsakingo vartojimo Lietuvoje mastai.

Tyrimo objektas - socialiai atsakingas vartojimas.

Tyrimo tikslas: nustatyti socialiai atsakingo vartojimo mastus Lietuvoje ir socialiai atsakingus vartotojus, atsižvelgiant ị demografines ir socialines charakteristikas.

Tyrimo uždaviniai:

- nustatyti socialiai atsakingų vartotojų charakteristikas;

- nustatyti socialiai atsakingo vartojimo Lietuvoje mastus.

Tyrimo metodai: lyginamoji mokslinès literatūros analizè ir sintezè, sisteminimas, apibendrinimas, empirinis tyrimas - apklausa ir gautų tyrimo duomenų statistinè analizè. 


\section{Socialiai atsakingas vartojimas Lietuvoje: empirinis tyrimas}

Socialiai atsakingos įmonès plètoja įmonių socialinès atsakomybès (ĮSA) iniciatyvas dèl skirtingų priežasčių: vienos - dèl ịtakos reputacijai ir teigiamo ịvaizdžio kūrimo, kitos - dèl finansinio atlygio. D. J. Webb ir kt. teigia, kad „socialinė atsakomybe atsiperka, kai vartotojai taiko İSA kaip pirkimo kriterijų“ (2008, p. 91). Todèl svarbu, kad įmonės žinotu, ar socialinė atsakomybẻ yra svarbi tiksliniams vartotojams.

Būtina paminèti, kad İSA dažnai netinkamai koordinuojama, labdaringa veikla nesusijusi su įmonès strategija ir neturi reikšmingo socialinio poveikio, todėl neskatinamas įmonių ilgalaikis konkurencingumas. Bendrovių pastangos patenkinti suinteresuotụjų ar spaudimo grupių lūkesčius dažnai būna nesusijusios, o tai mažina ịmonių socialinę ịtaką. Viso to pasekmès būna prarastos galimybės ịgyvendinti tiek vartotojų, tiek verslo tikslus (Porter et al., 2006, p. 83). Suprantama, kad verslas negali išspręsti visų visuomenès problemų ar finansuoti problemų likvidavimo. Vietoj to kiekviena bendrovè turètų pasirinkti probleminę sritị, kuri suteiktų verslui galimybę sukurti bendrą vertę (naudą tiek visuomenei, tiek verslui) (Porter et al., 2006, p. 84).

Nors šiuo metu Lietuvoje yra 65779 veikiančios įmonès ${ }^{1}$, iš jų tik 126 priklauso nacionaliniam atsakingo verslo tinklui ${ }^{2}$. Ateityje socialiai atsakingų įmonių turètų daugèti, nes Lietuvoje plinta socialiai atsakingo vartojimo iniciatyvos, įmonès skatinamos būti socialiai atsakingos. Taigi İSA kriterijus gali tapti vienu svarbiausių priimant sprendimą pirkti. Todèl turi būti ištirtos vartotojų preferencijos, kad būtų galima pateikti atitinkamas rekomendacijas dabartinèms ir būsimoms socialiai atsakingoms įmonėms rinkoje. Siekiant užtikrinti, kad socialiai atsakingus produktus gaminantis verslas dirbtų pelningai, būtina išsiaiškinti, ar Lietuvos vartotojai yra socialiai atsakingi ir kokios jų savybės nulemia socialiai atsakingos įmonès produkto pasirinkimą bei koks vartotojų segmentas perka tokias prekes, ir tikslingai i ji orientuotis.

1 Lietuvos statistikos departamentas [interaktyvus]. Prieiga internete: http://db1.stat.gov. 1t/statbank/selectvarval/saveselections.asp? MainTable=M4010241\&PLanguage $=0 \& \mathrm{~T}$ ableStyle $=\&$ Buttons $=\&$ PXSId $=13367 \& \mathrm{IQY}=\& \mathrm{TC}=\& \mathrm{ST}=\mathrm{ST} \& \mathrm{rvar} 0=\& \mathrm{rvar} 1=\& \mathrm{rvar} 2$ =\&rvar3=\&rvar4=\&rvar5=\&rvar6=\&rvar7=\&rvar8=\&rvar9=\&rvar10=\&rvar11=\&rv ar12=\&rvar13=\&rvar14= [žiūrèta 20131215$]$.

2 Socialinès apsaugos ir darbo ministerija. Socialiai atsakingos ịmonès Lietuvoje [interaktyvus]. Prieiga internete: http://www.socmin.lt/index.php?1402556533 [žiūrèta 201312 15]. 


\section{Empirinio tyrimo metodologija}

Siekiant nustatyti demografinių ir socialinių vartotojų charakteristikų bei socialiai atsakingo vartojimo ryši, atliktas kiekybinis tyrimas - anketinè apklausa. Kiekybinè duomenų analizè pagrįsta statistiniu patikimumu, koreliaciniu ryšiu ir kitais statistikos kriterijais (Mann-whitney, Spearman, phi). Kiekybiniu tyrimu siekta patvirtinti išsikeltas hipotezes:

H1 - pajamų pakankamumas ir išsilavinimas turi įtakos socialiai atsakingam elgesiui. Šia hipoteze siekta patikrinti, ar iš tiesų šie du veiksniai yra reikšmingi socialiai atsakingam elgesiui. Pasak D. Crane (2010, p. 376), A. Patino ir kt. (2014, p. 5), gaunamos pajamos yra susijusios su atsakingu vartojimu. Anot S. Kolkailah ir bendraautorių (2012, p. 382), socialiai atsakingam vartojimui didelę įtaką daro ir igytas išsilavinimas, nes išsilavinę žmonès pasižymi socialiai atsakingesniu požiūriu ị vartojimą.

H2 - moterys yra socialiai atsakingesnès vartotojos negu vyrai. Šia hipoteze siekiama išsiaiškinti, ar Lietuvos moterys yra atsakingesnès vartotojos ir jautresnès socialinėms problemoms nei vyrai, kaip teigia J. Bray ir kt. (2011, p. 599).

H3 - jaunesni vartotojai dažniau atsižvelgia ị İSA, priimdami sprendimą pirkti, negu vyresni. Tarptautinès tyrimų bendrovès „Nielsen“ ataskaitos duomenimis (A Nielsen Report The Global, Socially-Conscious Consumer, 2012), jaunesni vartotojai yra socialiai atsakingesni nei vyresni ir labiau linkę mokèti papildomą kainą už socialiai atsakingų įmonių prekes ir paslaugas, todèl gali būti labiau linkę atsiŽvelgti ir į İSA priimdami sprendimą pirkti.

H4 - egzistuoja glaudus ryšys tarp vartotojų informuotumo ir socialiai atsakingo elgesio. T. Newholm ir kt. teigia, kad informacija yra būtina socialiai atsakingo vartojimo sąlyga. Autorių teigimu, gerai informuoti vartotojai ne tik reikalauja sąžiningos prekybos produktų, bet ir nori, kad gamintojai bei tiekèjai pagristų produktų deklaruojamas etines savybes (Newholm, Shaw, 2007, p. 256). A. D’Astous ir kt. mano, kad kuo daugiau vartotojai žino apie socialiai atsakingą vartojimą, tuo atsakingiau vartoja (D’Astous, Legendre, 2009, p. 263).

H5 - socialiai atsakingiems vartotojams svarbi įmonių pozicija dẻl socialinès atsakomybės. Šia hipoteze siekiama patikrinti, ar iš tikrujų vartotojai, reikalaujantys vis daugiau informacijos apie İSA, yra socialiai atsakingi ir kiek jiems svarbi ISA priimant sprendimus pirkti.

H6 - socialiai atsakingi vartotojai domisi perkamais produktais ir skaito produkto etiketeje pateiktą informaciją. Ši hipotezè remiasi prielaida, kad socialiai atsakingi vartotojai vengia skubotų sprendimų ir atidžiai renkasi perkamas prekes bei papildomai domisi vartojamais produktais. 
Taigi siekiant geriau suprasti Lietuvos vartotoju požiūrị i socialiai atsakingą vartojimą, šiuo tyrimu norima nustatyti ne tik socialiai atsakingo vartojimo lygi Lietuvoje, bet ir tai, kas vartotojams svarbiausia vertinant ISA, ir ar tai priklauso nuo lyties, amžiaus, vartotojo pajamų. Pasak Y. Ozkan (2009, p. 949), A. Patino ir kt. (2014, p. 4), tiriant atsakingą elgesį ir vertinant požiūrị galima atrasti sąsajų su demografinèmis charakteristikomis, todèl jomis ir socialinèmis charakteristikomis bei kitais veiksniais bus remiamasi siekiant nustatyti socialiai atsakingą vartotoją.

Tyrimo instrumentas - klausimynas (struktūruota anketa), sudarytas iš 4 klausimų grupių. Pirmos grupès klausimais siekta atskleisti vartotojų požiūrị i i̇monès elgesị: ar vartotojams svarbi İSA renkantis produktus ir ar jie atsižvelgia i I ISA priimdami pirkimo sprendimą bei kiek svarbūs konkretūs İSA veiksniai, kurie vertinti pagal Likerto penkiabalę skalę (5 - visiškai sutinku, 1 - visiškai nesutinku). Antros grupės klausimų bloku norèta nustatyti, ar vartotojų elgesys iš tiesų yra socialiai atsakingas. Šiam tikslui naudota socialiai atsakingo vartojimo elgesio skalè, kurią parengè Antil ir Bennett (Bearden et al., 1999, p. 139). Minètą skalę sudaro 40 klausimų (klausimai modifikuoti, t. y. pritaikyti Lietuvos vartotojams ir nagrinejjamam atvejui, dalis išbraukta, todèl bloką sudare 30 klausimu). Pasitelkus penkiabalę Likerto skalę ( 5 - visiškai sutinku, 1 - visiškai nesutinku) ịvertinti ir susumuoti atsakymai ị minètus klausimus, siekiant nustatyti socialiai atsakingo vartojimo elgesio indeksą (galimas rezultatas - 30-150, kur 150 - socialiai atsakingas elgesys, 30 - neatsakingas). Būtina pažymèti, kad tam tikri klausimai buvo klaidinantys ir vertinami atvirkščiai, siekiant išvengti nesąžiningų atsakymų bei atskleisti realų vartotojų elgesį. Kitais šio bloko klausimais siekta nustatyti, ar vartotojai yra pakankamai informuoti apie socialiai atsakingo vartojimo esmę (taip pat naudojant Likerto penkiabalę skalę), ar domisi konkretaus produkto ypatybėmis. Trečia klausimų grupė skirta nustatyti vartotojų demografines charakteristikas, ketvirtoji - socialines charakteristikas ir jų įtaką socialiai atsakingam elgesiui.

Kiekybinio tyrimo generaline aibe - visi Lietuvos gyventojai. Lietuvos statistikos departamento duomenimis, 2014 m. pradžioje Lietuvos gyventojų skaičius buvo $2944459^{3}$.

3 Lietuvos statistikos departamentas [interaktyvus]. Prieiga internete: http://db1.stat.gov. lt $/$ statbank/selectvarval/saveselections.asp? MainTable $=$ M3010211\&PLanguage $=0 \& \mathrm{~T}$ ableStyle $=\&$ Buttons $=\&$ PXSId $=3767 \& I Q Y=\& T C=\& S T=$ ST \&rvar0=\&rvar $1=\&$ rvar $2=$ \&rvar3=\&rvar4=\&rvar5=\&rvar6=\&rvar7=\&rvar8=\&rvar9=\&rvar10=\&rvar11=\&rvar 12=\&rvar13=\&rvar14= [žiūrèta 20140111$]$. 


\section{Tyrimo rezultatų analizè ir interpretacija}

Tyrimo metu apklausti 306 Lietuvos vartotojai (139 vyrai, 164 moterys, trys respondentai savo lyties nenurodè). Galima teigti, kad apklaustujų skaičius santykinai proporcingas Lietuvos gyventojų skaičiui ir sudaro panašų procentą (1 lentelè). Taigi tyrimas atskleidžia realią Lietuvos vartotojų demografinę sudètị lyties atžvilgiu.

1 lentelè. Respondentų pasiskirstymas pagal lytị

\begin{tabular}{|l|c|c|}
\hline \multicolumn{1}{|c|}{ Lytis } & Apklausti respondentai (\%) & Lietuvos populiacija (\%) \\
\hline Vyras & 45,9 & 46,1 \\
\hline Moteris & 54,1 & 53,9 \\
\hline
\end{tabular}

Surinkus ir apdorojus respondentų atsakymus nustatytas socialiai atsakingo vartojimo lygis Lietuvoje. Kaip minèta, Lietuvos vartotojų socialinis atsakingumas buvo nustatomas remiantis Antil ir Bennett socialiai atsakingo vartojimo elgesio skale. Skalè suskirstyta ị tris intervalus $(30-79 ; 80-119 ; 120-150)$ ir laikoma, kad kiekvienas intervalas atskleidžia vartotojų socialinę atsakomybę (nuo socialiai neatsakingų iki atsakingų). Taigi atlikus tyrimą nustatyta, kad didžioji dalis respondentų yra socialiai atsakingi - 63,7 \% (195 respondentai), kur kas mažiau - vidutiniškai atsakingi 30,1\% (92 respondentai) ir tik nedidelè dalis - socialiai neatsakingi $6,2 \%$ (19 respondentu) (1 pav.).

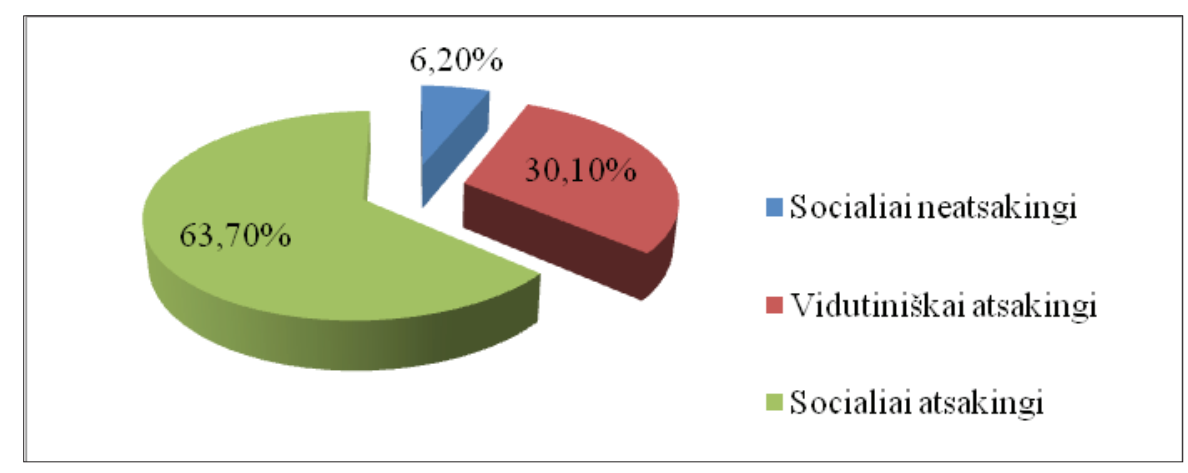

1 pav. Lietuvos vartotojų socialinis atsakingumas

4 Lietuvos statistikos departamentas [interaktyvus]. Prieiga internete: http://db1.stat. gov.lt/statbank/selectvarval/saveselections.asp?MainTable=M3010206\&PLanguage $=0 \&$ TableStyle $=\&$ Buttons $=\& P x s i d=3212 \&$ TC $=0 \&$ UseDots $=$ True $\& S T=S T \quad$ [žiūrèta 201404 05]. 
Nors didžioji dauguma apklaustujų save identifikuoja kaip socialiai atsakingus vartotojus ir išreiškia susirūpinimą visuomenès bei aplinkos problemomis, tačiau tyrimas atskleidè, kad vartotojai, rinkdamiesi prekes, vis dèlto prioritetą teikia tokiems prekių / paslaugų požymiams kaip kaina, kokybė, patikimumas, klientų aptarnavimas, produktų garantijos terminas ir kt., o ne I̦SA (2 pav.)

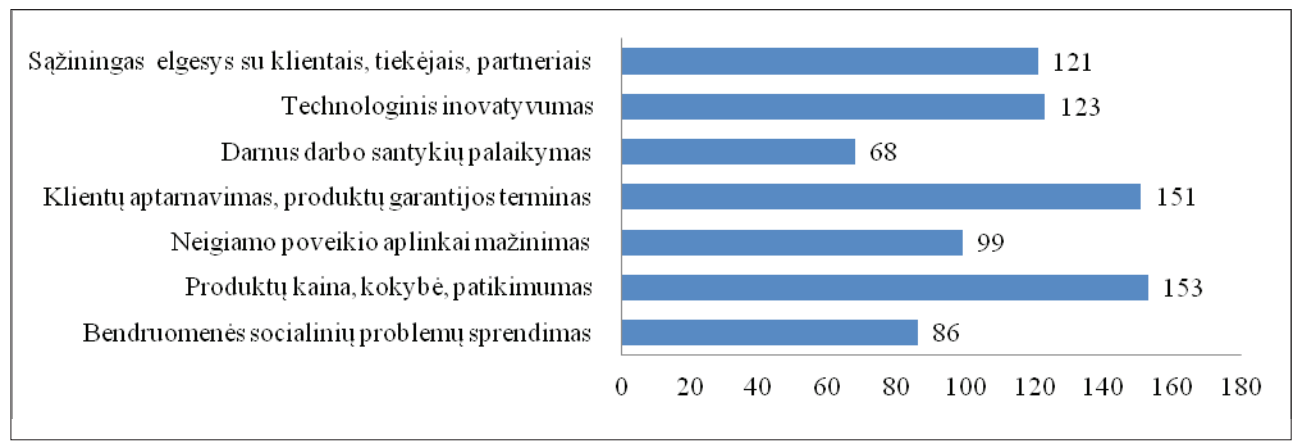

2 pav. Veiksniai, lemiantys konkrečios įmonès produktų pasirinkimą

Vieni svarbiausių veiksnių vertinant İSA yra ịmonės sprendžiamos socialinės problemos ir pastangos mažinti neigiamą poveikị aplinkai (3 pav.), nors priimant sprendimą pirkti jie kur kas mažiau reikšmingi (2 pav.). Remiantis šiais rezultatais galima teigti, kad vartotojai pageidauja, jog ịmonès elgtųsi socialiai atsakingai, bet tai dar negarantuoja, kad vartotojai pirks būtent iš tokių įmonių. Galutinis pirkimo sprendimas priimamas dažniausiai atsižvelgiant ị kainą, kokybę, aptarnavimą ir garantiją. Vis dèlto galima teigti, kad vartotojai iš tiesų yra sąmoningi ir ịmonėms kelia tam tikrus reikalavimus, nes suvokia jų vykdomos veiklos reikšmę visuomenei bei aplinkai.

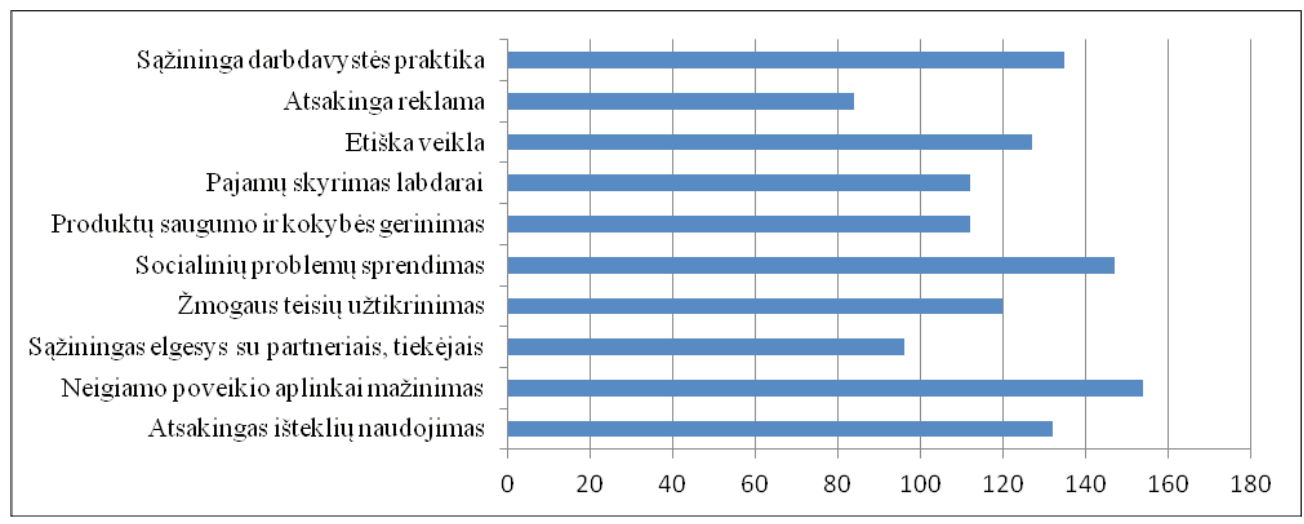

3 pav. Veiksniai, darantys ịtaką İSA vertinimui 
Europos mastu socialiai atsakingiems vartotojams svarbiausia, kad ịmonės būtų draugiškos aplinkai. Kiek mažiau svarbios, tačiau taip pat reikšmingos šios sritys (prioritetu mažèjimo tvarka): visuomenès skurdo ir alkio eliminavimas; parama smulkiajam verslui; prieinamumo prie švaraus vandens didinimas; diskriminacijos šalinimas (Nielsen Report, 2012, p. 7).

Remiantis atliktu tyrimu galima paminèti, kad nors vartotojai priima pirkimo sprendimą remdamiesi kaina, kaip vienu iš kriterijų, ta kaina neprivalo būti mažesnè ar atitikti alternatyvių produktų kainą, nes didžioji dalis tyrime dalyvavusių respondentų sutiktų mokèti papildomai už socialiai atsakingų ịmonių produktus (4 pav.). Tokie tyrimo rezultatai rodo, kad vartotojai iš tiesų supranta İSA veiklos svarbą ir sutinka ją remti.
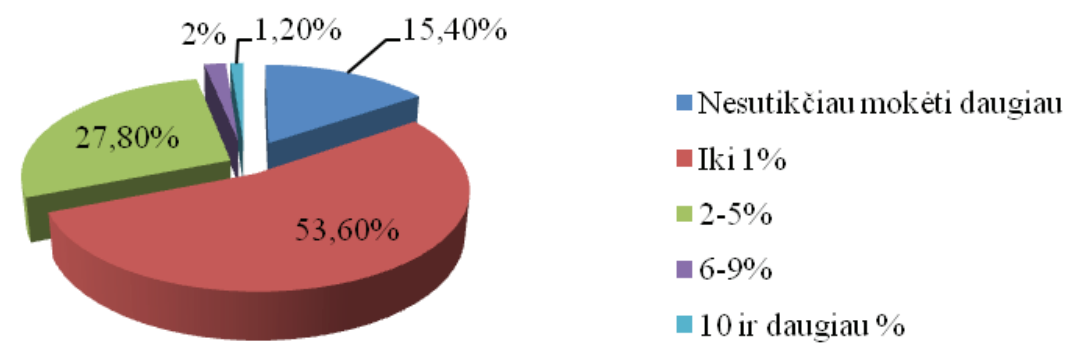

4 pav. Kiek vartotojai sutiktų papildomai mokèti už socialiai atsakingų imonių prekes

Būtina akcentuoti, kad trijų pagrindinių klausimynų, kurie naudoti tikrinant hipotezes, skirstiniai statistiškai reikšmingai skyrèsi nuo normaliujų (nes $p<0,05$ ), todèl taikyta neparametrinè statistika (2 lentelè).

2 lentelè. Normalumo reikšmès

\begin{tabular}{|l|l|l|}
\hline \multicolumn{1}{|c|}{ Klausimynas } & Shapiro-Wilk testo reikšmé & $p$ reikšmé \\
\hline ISA & 0,972 & $<0,0001$ \\
\hline Socialiai atsakingas elgesys & 0,933 & $<0,0001$ \\
\hline Vartotojų informuotumas & 0,968 & $<0,0001$ \\
\hline
\end{tabular}

\subsection{Pajamu pakankamumo ir išsilavinimo ịtaka socialiai atsakingam elgesiui}

Analizuojant pajamų pakankamumo įtaką socialiai atsakingam elgesiui būtina pažymèti, kad respondentų dalis, vertinanti savo pajamas kaip pakankamas arba nepakankamas, skiriasi nedaug (5 pav.). 


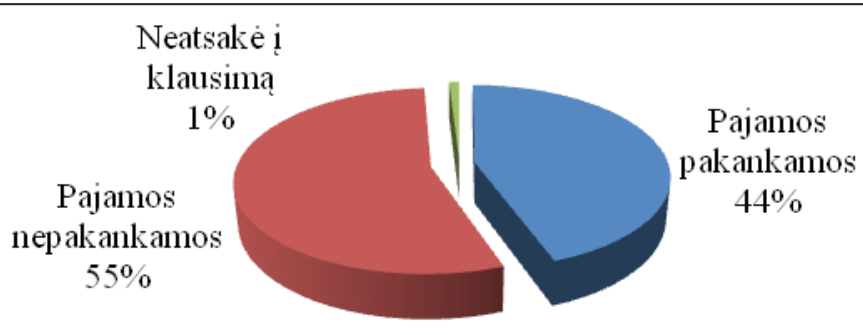

5 pav. Pajamų pakankamumo vertinimas

Siekiant nustatyti pajamų pakankamumo ịtaką socialiai atsakingam elgesiui taikytas Mann-Whitney testas, nes jis yra neparametrinis (patikrinus duomenų normalumą, nustatyta, kad jie pasiskirstę nenormaliai) ir ieškota skirtumų tarp dviejų grupių (3 lentelè).

3 lentelè. Pajamų pakankamumo įtaka socialiai atsakingam elgesiui

\begin{tabular}{|c|c|c|c|}
\hline Mann-Whitney U & \multirow{2}{*}{$p$ reikšmé } & \multicolumn{2}{|c|}{ Mediana } \\
\cline { 3 - 4 } & & Taip & $\mathrm{Ne}$ \\
\hline 5293 & $<0,0001$ & 135 & 121,5 \\
\hline
\end{tabular}

Remiantis Mann-Whitney testo rezultatais galima teigti, kad egzistuoja statistiškai reikšmingi skirtumai (nes $p<0,05$ ) tarp žmonių, vertinančių savo pajamas kaip pakankamas, ir žmonių, vertinančių jas kaip nepakankamas, socialiai atsakingo elgesio. Žmonių, kurie vertina savo pajamas kaip pakankamas, elgesys yra labiau socialiai atsakingas nei žmonių, vertinančių savo pajamas kaip nepakankamas.

Vertinant išsilavinimo įtaką socialiai atsakingam elgesiui reikia pasakyti, kad didžioji dauguma apklaustujų yra igiję aukštajị išsilavinimą, todẻl netinkamai atskleistas žemesni išsilavinimą turinčių asmenų vartojimo elgesys (6 pav.).

Ieškant sąsajų tarp išsilavinimo ir socialiai atsakingo elgesio taikytas Spearmano koreliacijos koeficientas, nes duomenys pasiskirstę nenormaliai, todèl reikèjo ieškoti koreliacijų tarp 2 kintamųjų (4 lentelè). 


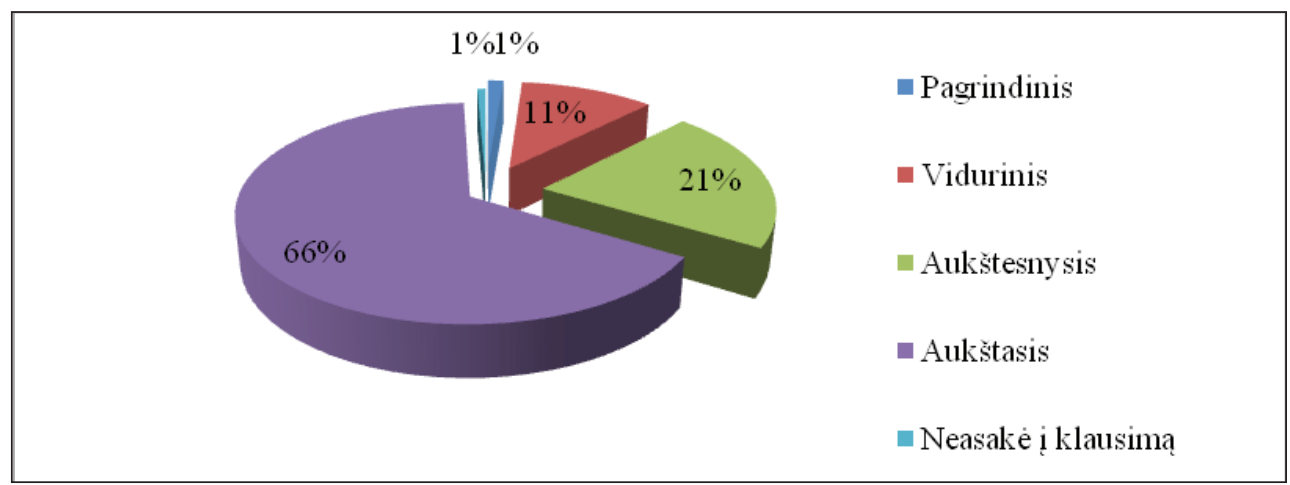

6 pav. Respondentų ịgytas išsilavinimas

4 lentelè. Išsilavinimo ịtaka socialiai atsakingam elgesiui

\begin{tabular}{|l|l|}
\hline Spearman rho & $p$ reikšmé \\
\hline 0,25 & $<0,0001$ \\
\hline
\end{tabular}

Nepaisant netolygaus respondentų pasiskirstymo išsilavinimo atžvilgiu, išsilavinimas ir socialiai atsakingas elgesys statistiškai reikšmingai susiję (nes $p<0,05$ ). Sąsaja teigiama ir labai silpna. Taigi, kuo aukštesnis išsilavinimas, tuo labiau pasireiškia socialiai atsakingas elgesys.

Apibendrinant galima teigti, kad pirmoji hipotezè, kad pajamų pakankamumas ir išsilavinimas turi įtakos socialiai atsakingam elgesiui, yra patvirtinta. Taigi socialiai atsakingos įmonès turi orientuotis ị didesnes pajamas gaunančius ir labiau išsilavinusius vartotojus. Be to, svarbu, kad ir pati šalies vyriausybė skatintų atsakingą vartojimą šviesdama vartotojus, tai gali prisidèti keliant jų sąmoningumą.

\subsection{Lyties itaka socialiai atsakingam vartojimui}

Kaip minėta, tyrime dalyvavo panašus vyrų ir moterų skaičius, atskleidžiantis realią Lietuvos gyventojų sudėtį. Siekiant patikrinti antrają hipotezę, ar moterys iš tiesų atsakingesnès vartotojos nei vyrai, taikytas Mann-Whitney kriterijus, kadangi duomenys pasiskirstę nenormaliai ir lyginamos dvi grupès (5 lentelè).

5 lentele. Lyties ittaka socialiai atsakingam vartojimui

\begin{tabular}{|l|c|c|c|}
\hline Mann-Whitney U & \multirow{2}{*}{$p$ reikšmé } & \multicolumn{2}{|c|}{ Mediana } \\
\cline { 3 - 4 } & & Vyrai & Moterys \\
\hline 5630 & $<0,0001$ & 121,5 & 133 \\
\hline
\end{tabular}


İvertinus gautus duomenis galima teigti, kad vyrų ir moterų socialiai atsakingas elgesys statistiškai reikšmingai skiriasi (nes $p<0,05$ ). Moterų elgesys yra labiau socialiai atsakingas nei vyrų, todèl antroji hipotezè taip pat patvirtinta. Remiantis tyrimo rezultatais, socialiai atsakingos įmonès turètų labiau orientuotis ị moteris, ieškoti būdų, kaip patraukti jų dėmesį sprendžiant joms aktualias socialines problemas ir taip pelnyti jų palankumą.

A. Patino ir kt. teigia, kad vyrų ir moterų požiūriai ị socialiai atsakingą vartojimą skiriasi ir šie skirtumai yra moralinio pobūdžio. Vyrai yra labiau linkę vertinti įmonę atsižvelgdami ị tai, kaip ji laikosi taisyklių ir užtikrina asmens teises, o moterys labiau linkusios vertinti ịmonès elgesị bendruomeniniu požiūriu (rūpinimasis kitais, santykiai, veikla kitų labui). Be to, būtina pastebèti, kad moterys labiau linkusios vertinti įmonès veiklą kaip neetišką, jei įmone pateikia klaidingą informaciją, ịsitraukia ị interesų konfliktą ir t. t. Vyrai ir moterys interpretuoja elgesị pagal tam tikrus stereotipus, kurie susiję su tuo metu užimama visuomenine padètimi (Patino et al., 2014, p. 4). Galima teigti, kad šiuo tyrimu nustatyta ne tik lyties įtaka požiūriui ị socialiai atsakingą vartojimą, bet ir pati socialiai atsakinga elgsena.

\subsection{Amžiaus ịtaka priimant l̦A kriterijumi paremtus sprendimus}

Analizuojant amžiaus ịtaką İSA kriterijumi paremtų sprendimų prièmimui išskirtos dvi grupès - jaunesnių (iki 32 metų - 172) ir vyresnių (nuo 33 metų - 133) respondentų (7 pav.).

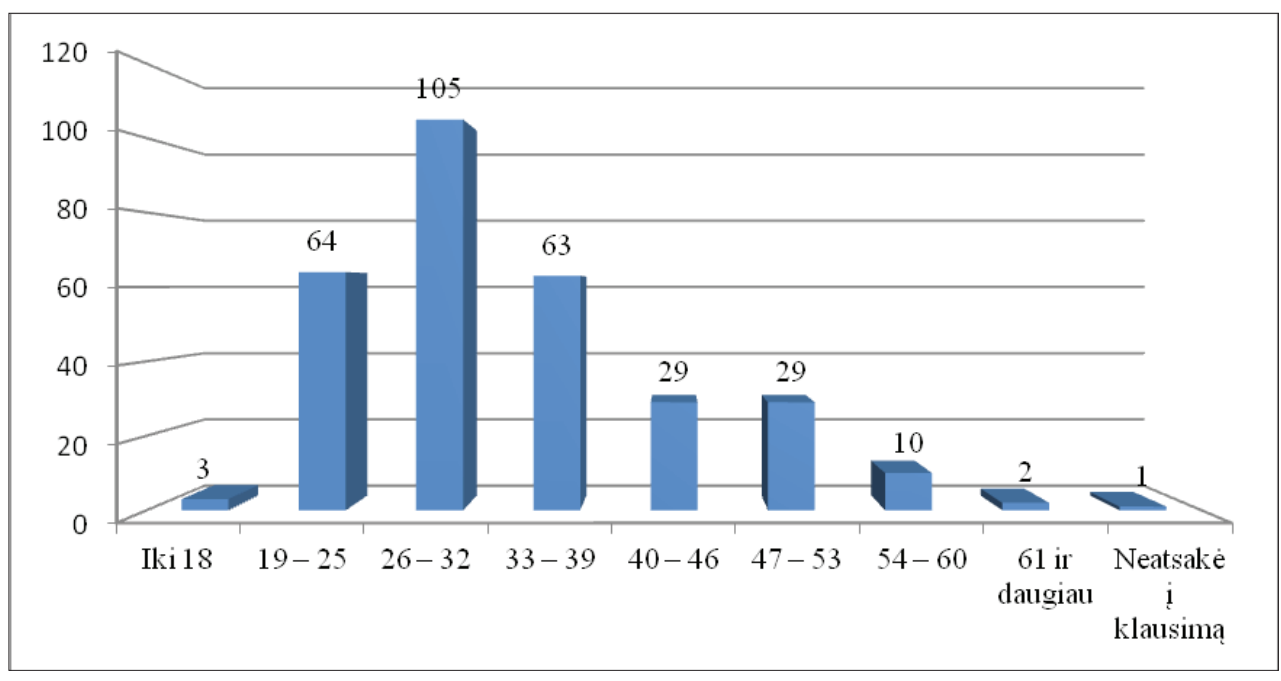

7 pav. Respondentų amžius 
Duomenys buvo nenormaliai pasiskirstę, todèl taikytas Mann-Whitney kriterijus ir palygintos dvi grupès (6 lentelè).

6 lentelè. Amžiaus įtaka İSA kriterijumi paremtų sprendimų prièmimui

\begin{tabular}{|l|c|l|l|}
\hline Mann-Whitney U & \multirow{2}{*}{$p$ reikšmé } & \multicolumn{2}{|c|}{ Mediana } \\
\cline { 3 - 4 } & & Iki 32 m. & Virš 33 m. \\
\hline 10025,5 & 0,136 & 15 & 15 \\
\hline
\end{tabular}

Remiantis gautais rezultatais, nėra statistiškai reikšmingų skirtumų tarp jaunesnių ir vyresnių tiriamujjų (nes $p>0,05$ ). Trečioji hipotezè negali būti patvirtinta, todèl jaunesni vartotojai atsižvelgia ị İSA kriterijų priimdami pirkimo sprendimą ne dažniau nei vyresni. Būtina pridurti, kad šio tyrimo rezultatai gali papildyti tarptautinès tyrimų bendrovès „Nielsen“ atliktą tyrimą, kurio ataskaitos duomenimis (A Nielsen Report The Global, Socially-Conscious Consumer, 2012) jaunesni vartotojai yra socialiai atsakingesni nei vyresni. Nors „Nielsen“ tyrimo duomenimis jaunesni vartotojai yra labiau linkę mokèti papildomą kainą už socialiai atsakingų įmonių prekes ir paslaugas, nėra aiškių požymių, kad Lietuvos vartotojai priimdami sprendimą pirkti i İ ISA atsižvelgtų dažniau nei vyresni.

\subsection{Vartotoju informuotumo ir socialiai atsakingo vartojimo sąaja}

Norinti nustatyti, ar egzistuoja ryšys tarp vartotojų informuotumo ir socialiai atsakingo elgesio, taikytas Spearmano koreliacijos koeficientas ir ieškoma koreliacijų tarp dviejų kintamųjų, nes duomenys buvo nenormaliai pasiskirstę (7 lentelè).

7 lentele. Ryšys tarp vartotojų informuotumo ir socialiai atsakingo elgesio

\begin{tabular}{|l|l|}
\hline Spearman rho & $p$ reikšmé \\
\hline 0,655 & $<0,0001$ \\
\hline
\end{tabular}

Remiantis 7 lenteleje pateiktais duomenimis, vartotojų informuotumas ir socialiai atsakingas elgesys statistiškai reikšmingai susiję (nes $p<0,05$ ). Taigi ryšys yra teigiamas ir vidutinio dydžio. Didejjant vartotojų informuotumui, vartotojai elgiasi socialiai atsakingiau, todèl ketvirtoji hipotezè patvirtinta. Duomenys pagrindžia prielaidą, kad kuo daugiau vartotojai žino apie socialiai atsakingą vartojimą, tuo atsakingiau vartoja. Siekiant skatinti socialiai atsakingą vartojimą būtina suteikti vartotojams pakankamai informacijos apie İSA, paaiškinti neatsakingo vartojimo pasekmes visuomenei ir gamtai, t. t. 


\subsection{ISA svarba socialiai atsakingiems vartotojams}

Siekiant nustatyti İSA svarbą socialiai atsakingiems vartotojams, taikytas Spearmano koreliacijos koeficientas ir ieškota koreliacijos tarp 2 intervalinių kintamųjų (duomenys nenormaliai pasiskirstę) (8 lentelè).

8 lentele. İSA svarba socialiai atsakingiems vartotojams

\begin{tabular}{|l|l|}
\hline Spearman rho & $p$ reikšmé \\
\hline 0,409 & $<0,0001$ \\
\hline
\end{tabular}

İSA ir socialiai atsakingas elgesys yra statistiškai reikšmingai susiję (nes $p<0,05)$, ryšys yra teigiamas ir silpnas. Todèl didejjant İSA, išryškejja ir socialiai atsakinga elgsena. Taigi penktoji hipotezė patvirtinta: socialiai atsakingiems vartotojams svarbi įmonių veikla paisant socialinès atsakomybès, jie ị tai atsižvelgia priimdami sprendimus pirkti. Tačiau remiantis anksčiau pateiktomis įžvalgomis, galima teigti, kad nors hipotezė ir patvirtinta, vartotojai, prieš priimdami galutini sprendimą pirkti, atsižvelgia ne ị İSA, o ị prekių kainą, kokybę bei garantiją.

\subsection{Socialiai atsakingo elgesio ir domëjimosi perkamais produktais ry̌̌ys}

Empirinio tyrimo duomenys rodo, kad didžioji dauguma respondentų domisi perkamais produktais ir ieško papildomos informacijos apie produktą, kuri ketina ịsigyti $(81 \%)$. Norint nustatyti, ar egzistuoja ryšys tarp domejjimosi ir socialiai atsakingo elgesio, taikytas Mann-Whitney kriterijus, siekiant palyginti dvi grupes (duomenys nenormaliai pasiskirstę) (9 lentelè).

9 lentelè. Ryšys tarp domèjimosi produktais ir socialiai atsakingo elgesio

\begin{tabular}{|c|c|c|c|}
\hline \multirow{2}{*}{ Mann-Whitney U } & \multirow{2}{*}{$p$ reikšmé } & \multicolumn{2}{|c|}{ Mediana } \\
\cline { 3 - 4 } & & Taip & Ne \\
\hline 3853,5 & $<0,0001$ & 130 & 120,5 \\
\hline
\end{tabular}

Remiantis pateiktos lentelès duomenimis galima teigti, kad yra statistiškai reikšmingų skirtumų tarp vartotojų, ieškančių papildomos informacijos apie produktą, ir vartotojų, kurie jos neieško, socialiai atsakingo elgesio (nes $p<0,05$ ). Vartotojai, kurie ieško papildomos informacijos apie produktą, yra labiau socialiai atsakingi negu vartotojai, kurie papildomos informacijos neieško.

Analizuojant vartotojų atsakymus apie informacijos, pateiktos produkto etiketèje, skaitymą galima teigti, kad didžioji dauguma yra linkę susipažinti su pro- 
duktu ir vengia skubotu sprendimu (84 \%). Siekiant nustatyti, ar yra ryšys tarp socialiai atsakingo elgesio ir produktų etikečių skaitymo, taikytas Mann-Whitney kriterijus ir lyginamos dvi grupès (duomenys nenormaliai pasiskirstę) (10 lentelè).

10 lentele. Ryšys tarp produktų etikečių skaitymo ir socialiai atsakingo elgesio

\begin{tabular}{|c|c|c|c|}
\hline Mann-Whitney U & \multirow{2}{*}{$p$ reikšmė } & \multicolumn{2}{|c|}{ Mediana } \\
\cline { 3 - 4 } & & Taip & $\mathrm{Ne}$ \\
\hline 2952 & $<0,0001$ & 129 & 118 \\
\hline
\end{tabular}

Remiantis pateiktais rezultatais galima daryti išvadą, kad egzistuoja statistiškai reikšmingi skirtumai tarp vartotojų, skaitančių informaciją, pateiktą produktų etiketejje, ir jos neskaitančių socialiai atsakingo elgesio (nes $p<0,05$ ). Vartotojai, skaitantys informaciją, pateiktą produktų etiketėse, yra labiau socialiai atsakingi negu vartotojai, kurie tokios informacijos neskaito.

Nustatyta, kad socialiai atsakingi vartotojai yra linkę domètis perkamais produktais ir skaityti informaciją produktų etiketèse, naudinga nustatyti ir sąsają tarp tokio elgesio bei lyties. Kadangi duomenys yra nominaliniai dichotominiai (jų negalima skirstyti rangais), taikomas Phi testas (11 lentelè).

11 lentele. Sąsajos tarp lyties ir domèjimosi etiketėmis bei papildomos informacijos ieškojimo

\begin{tabular}{|l|l|l|l|}
\hline \multicolumn{2}{|c|}{ Klausimas } & \multicolumn{2}{c|}{ Lytis } \\
\cline { 3 - 4 } \multicolumn{2}{|c|}{} & \multicolumn{1}{|c|}{ Vyras } & \multicolumn{1}{c|}{ Moteris } \\
\hline Ar skaitote produktų etiketėse pateiktą informaciją? & Taip & $35,8 \%$ & $64,2 \%$ \\
\cline { 2 - 4 } & Ne & $98,0 \%$ & $2,0 \%$ \\
\hline Ar ieškote papildomos informacijos apie produktą, kurị & Taip & $39,1 \%$ & $60,9 \%$ \\
\cline { 2 - 4 } ketinate įsigyti? & Ne & $72,9 \%$ & $27,1 \%$ \\
\hline
\end{tabular}

\begin{tabular}{|l|c|l|}
\hline \multicolumn{1}{|c|}{ Klausimas } & $P h i$ & $p$ reikšmė \\
\hline Ar skaitote produktų etiketėse pateiktą informaciją? & $-0,459$ & $<0,0001$ \\
\hline $\begin{array}{l}\text { Ar ieškote papildomos informacijos apie produktą, kurị ketinate } \\
\text { isigyti? }\end{array}$ & $-0,269$ & $<0,0001$ \\
\hline
\end{tabular}

Išanalizavus duomenis galima teigti, kad sąsajos tarp lyties ir produktų etikečių skaitymo statistiškai reikšmingos. Sąsaja neigiama ir vidutinè stipri. Tai, kad sąsaja neigiama, rodo dažnesni moterų atsakymai „taip“, „,ne“ dažniau atsakinèjo vyrai. Sąsajos tarp lyties ir papildomos informacijos apie produktą ieškojimo statistiškai reikšmingos. Sąsaja neigiama ir vidutinio dydžio. Moterys labiau ieško informacijos nei vyrai. 
Taigi šeštoji hipotezė pasitvirtino: socialiai atsakingi vartotojai labiau domisi perkamais produktais ir skaito informaciją, pateiktą produkto etiketeje, nei neatsakingi vartotojai. Be to, būtina pažymèti, kad tokie vartotojai dažniausiai yra moterys. Remdamosi šiais rezultatais, įmonès turètų ne tik sudaryti informacijos prieinamumo sąlygas vartotojams, bet ir pasirūpinti tos informacijos kokybe bei tikslingumu, t. y. padaryti kuo informatyvesnes produkto etiketes, kurios ne tik supažindintų su produkto sudètimi, kilmès šalimi, bet ir užsimintų apie vykdomą socialiai atsakingą veiklą. Informacija turi būti pateikiama subtiliai, kartu naudojant priemones, kurios patrauktų būtent moterų dèmesị. Norint tokias priemones nustatyti, reikia atlikti nuodugnesnį tyrimą.

\section{Išvados}

1. Nors tyrimas neatskleidè reikšmingos koreliacijos tarp amžiaus ir atsiŽvelgimo ị İSA priimant sprendimą pirkti, galima teigti, kad vyresni žmonès yra socialiai atsakingesni. Ši išvada remiasi atlikto tyrimo ir jaunimo nuostatų bei požiūrių į atsakingą vartojimą tyrimo rezultatų palyginimu. Atliekant tyrimą nustatyta, kad socialiai atsakingas vartojimas nepopuliarus tarp jaunimo (55,2\%), šis tyrimas atskleidè, kad 63,7 \% Lietuvos vartotojų yra socialiai atsakingi. Galima daryti prielaidą, kad rezultatų skirtumas atsirado dẻl skirtingo respondentų amžiaus: dauguma šio tyrimo respondentų buvo vyresni nei $25 \mathrm{~m}$., o tiriant jaunimo nuostatas ir požiūrius i atsakingą vartojimą apklausti asmenys nuo 16 iki 25 m., tai rodo, kad vyresni asmenys yra labiau linkę socialiai atsakingai vartoti nei jaunesni.

2. Empirinis tyrimas pagrindžia prielaidas, kad įmonių socialinė atsakomybė nèra dominuojantis kriterijus, kuris lemtų vartotojo apsisprendimą įsigyti prekę / paslaugą, nes kaina ir kokybė išlieka svarbiausi pasirinkimo kriterijai. Kita vertus, Lietuvoje yra nemažai socialiai atsakingų vartotojų, taigi socialiai atsakingų i̇monių produktai turi paklausą.

3. Socialines iniciatyvas plètojančioms įmonẻms turètų būti svarbu žinoti, kad didžioji dalis respondentų sutiktų mokèti aukštesnę kainą už atsakingų įmonių produkciją, jei ji būtų neprastesnès kokybès nei alternatyvių produktų, o tai reiškia, kad socialiai atsakingi vartotojai vertina tokias pastangas ir už jas atsilygina (šiuo atveju sutikdami mokèti aukštesnę kainą).

4. Didžioji dalis vartotojų (daugiausiai moterys) ieško informacijos apie perkamus produktus ir skaito prekių etiketes, tai reiškia, kad Lietuvos vartotojai nèra pasyvūs ir nelaukia, kol informacija juos pati pasieks. Lietuvos 
vartotojai negaili laiko ir pastangų rinkdamiesi geriausią produktą, todèl ypač svarbu sudaryti visas sąlygas tą informaciją gauti.

5. Remdamiesi tyrimo rezultatais galime nusakyti potencialaus socialiai atsakingų produktų pirkèjo profilị - įvairaus amžiaus (tikètina, kad vyresnè nei 25 metų), didesnes pajamas gaunanti, išsilavinusi moteris, kuri ieško informacijos apie perkamus produktus ir skaito etiketes bei vertindama ISA daugiausiai dèmesio skiria įmonès pastangoms mažinti neigiamą poveikį aplinkai ir spręsti bendruomenès socialines problemas.

\author{
Gauta 20150412 \\ Pasirašyta publikuoti 20150608
}

\title{
Literatūra
}

Auger, P., Devinney, T. M. (2007). Do what consumers say matter? The misalignment of preferences with unconstrained ethical intention. Journal of business ethics 76 (4): 361-383. Prieiga internete: http://link.springer. com/article/10.1007\%2Fs10551-006-9287-y?LI=true.

A Nielsen Report The Global, Socially-Conscious Consumer. (2012). Prieiga internete: http://fi.nielsen.com/site/ documents/NielsenGlobalSocialResponsibilityReportMarch2012.pdf.

Bearden, W. O., Netemeyer, R. G. (1999). Handbook of marketing scales: multi-item measures for marketing and consumer behaviour research. London: SAGE Publications, $139 \mathrm{p}$.

Boulstridge, E., Carrigan, M. (2000). Do consumers really care about corporate responsibility? Highlighting the attitude-behaviour gap. Journal of Communication Management 4 (4): 355-368. Prieiga internete: http://oro. open.ac.uk/15171/2/Boulstridge_and_Carrigan_Jnl_of_Communication_2000.pdf.

Bray, J., Johns, N., Kilburn, D. (2011). An Exploratory Study into the Factors Impeding Ethical Consumption. Journal of business ethics 98: 599. Prieiga internete: http://rd.springer.com/content/pdf/10.1007\%2 Fs10551-010-0640-9.

Castaldo, S., Perrini, F., Misani, N., Tencati, A. (2009). The missing link between corporate social responsibility and consumer trust: the case of fair trade products. Journal of business ethics 84 (1): 1-15.

Cornelissen, G., Cojuharenco, I., Karelaia, N. (2011). One person in the battlefield is not a warrior: self-construal, perceived ability to make a difference, and socially responsible behavior. Prieiga internete: http://www. insead.edu/facultyresearch/research/doc.cfm?did $=48748$.

Crane, D. (2010). Environmental change and the future of consumption: implications for consumer identity. Anuario Filosofico 43 (2): 353-379.

D'Astous, A., Legendre, A. (2009). Understanding consumers' ethical justification: a scale for appraising consumers' reasons for not behaving ethically. Journal of business ethics 87 (2): 255-268.

Devinney, T. M., Auger, P., Eckhardt, G., Birtchnell, T. (2006). The Other CSR: Consumer Social Responsibility. Stanford Social Innovation Review, Fall: 30-37. Prieiga internete: http://papers.ssrn.com/sol3/papers. cfm?abstract_id=901863.

Durif, F., Boivin, C., Rajaobelina, L., Lecompte, A. (2010). Socially Responsible Consumers: Profile and Implications for Marketing Strategy. International review research papers 7 (6): 215-224. Prieiga internete: http:// www.wbiconpro.com/522-Fabien.pdf.

Kolkailah, S., Aish, E., El-Bassiouny, N. (2012). The impact of corporate social responsibility initiatives on consumers' behavioural intentions in the Egyptian market. International Journal of consumer studies 36 (4): 369-384. Prieiga internete: http://ezproxy.biblioteka.ku.lt:2061/doi/10.1111/j.1470-6431.2011.01070.x/abstr act;jsessionid=2907944721809258C7FBB91E2C9CB703.f04t04.

Kozar, J. M., Connell, K. Y. H. (2013). Socially and environmentally responsible apparel consumption: knowledge, attitudes and behaviors. Social responsibility Journal 9(2): 315-324. Prieiga internete: http://ezproxy. biblioteka.ku.lt:2073/journals.htm?issn=1747-1117\&volume $=9 \&$ issue $=2 \&$ articleid $=17089847 \&$ show $=$ ht $\mathrm{ml}$. 
Nacionalinė įmonių socialinès atsakomybės plètros 2009-2013 metų programa. Patvirtinta Lietuvos Respublikos Vyriausybės $2010 \mathrm{~m}$. sausio $12 \mathrm{~d}$. nutarimu Nr. 53: 1-15. Prieiga internete: http://www3.1rs.lt/pls/inter3/ dokpaieska.showdoc_1?p_id=426593

Newholm, T., Shaw, D. (2007). Studying the ethical consumer: a review of research. Journal of consumer behaviour 6 (5): 253-270. Prieiga internete: http://ezproxy.biblioteka.ku.lt:2061/store/10.1002/cb.225/asset/225 ftp.pdf?v=1\&t=hszyjfuk\&s=c017aa2b34cfbaa0ec6b46dcc138452fb49dd87d.

Patino, A., Kaltcheva, V., Marymount, L., Pitta, D., Sriram, V., Winsor, R. (2014). How important are different socially responsible marketing practices? An exploratory study of gender, race, and income differences. Journal of consumer marketing 31 (1): 4-5. Prieiga internete: http://ezproxy.biblioteka.ku.lt:2073/journals. htm?articleid=17103879.

Porter, M. E., Kramer, M. R. (2006). Strategy \& society: the link between competitive advantage and corporate social responsibility. Harvard business review 84 (12): 83-84. Prieiga internete: http://ezproxy.biblioteka. ku.lt:2063/ehost/detail?vid=4\&sid=e908181d-d49d-4910-8a47-3e57636791df\%40sessionmgr4005\&hid=42 14\&bdata=JnNpdGU9ZWhvc3QtbG12ZQ\%3d\%3d\#db=bth\&AN=23081414.

Smith, N. C. (2007). Consumers as drivers of corporate responsibility. Centre for Marketing Working Paper 07-103: 1-33. Prieiga internete: http://195.130.87.21:8080/dspace/bitstream/123456789/1157/1/Consumers\%20as\%20drivers\%20of\%20corporate\%20responsibility.pdf.

Oberseder, M., Schlegelmilch, B., Gruber, V. (2011). Why don't consumers care about CSR? A qualitative study exploring the role of CSR in consumption decisions. Journal of Business Ethics 104 (4): 449-460. Prieiga internete: http://link.springer.com/content/pdf/10.1007\%2Fs10551-011-0925-7.

Ozkan, Y. (2009). The effect of some demographic characteristics of turkish consumers on their socially responsible consumption behaviours. World applied sciences Journal 6 (7): 946-960. Prieiga internete: http://www. idosi.org/wasj/wasj6(7)/12.pdf.

Valor, C. (2007). Can consumers buy responsibly? Analysis and solutions for market failures. Journal of Consumer Policy 31 (3): 315-326. Prieiga internete: http://link.springer.com/article/10.1007\%2Fs10603-0089070-9?LI=true.

Valor, C. (2005). Corporate social responsibility and corporate citizenship: towards corporate accountability. Business and society review 110 (2): 191-212. Prieiga internete: http://onlinelibrary.wiley.com/doi/10.1111/ j.0045-3609.2005.00011.x/full.

Webb, D. J., Mohr, L. A., Harris, K. E. (2008). A re-examination of socially responsible consumption and its measurement. Journal of business research 61: 91-98. Prieiga internete: http://ezproxy.biblioteka.ku.lt:2086/ science/article/pii/S0148296307001634.

\section{SOCIALLY RESPONSIBLE CONSUMPTION IN LITHUANIA: CONSUMERS PROFILE}

\section{Vytautas Juščius, Deimantẻ Dargienė}

\section{Summary}

The negative consequences of consumption for the environment and society encourage people to consume responsibly and to choose carefully which goods to purchase. For this reason, companies make investments in resources-efficient equipment and technology, seek to conserve natural resources, to reduce the harmful environmental impact of the production, take care of the staff working conditions and etc. Unfortunately, while consumers are increasingly interested in 
corporate social responsibility, researches reveal the existing gap between consumers interest in corporate social responsibility and use of this information when deciding whether or not to buy a particular product. Thus, although the majority of them argue in favor of socially responsible consumption and want to get more information from the companies about production of products/services and mitigation measures of impact to environment and public, very few are truly socially responsible consumers.

Currently there are 65779 operating companies in Lithuania, but only 126 belong to the national responsible business network. In the future, number of socially responsible companies should increase, because companies are encouraged to be socially responsible. In order to ensure that socially responsible companies would operate profitably, it is necessary to find out whether Lithuanian customers are socially responsible and which demographic and social characteristics of consumers lead them to buy products from socially responsible companies. To determine the connection between demographic and social characteristics of consumers and the socially responsible consumption quantitative research was made (306 consumers were surveyed) and the following hypothesis were confirmed: income adequacy and education affect the socially responsible behavior; women are more responsible consumers than men; there is a strong correlation between consumer awareness and socially responsible behavior; activity of companies in field of social responsibility are important for socially responsible consumers; socially responsible consumers are interested in the products they buy and read the information provided on the product label. Hypothesis that younger users are more likely to consider corporate social responsibility (CSR) before making a buying decision than older consumers were not confirmed.

The investigation revealed that the majority of respondents are socially responsible $-63.7 \%$ (195 respondents), significantly less is mediocre responsible $30.1 \%$ (92 respondents) and only a small part is socially irresponsible $-6.2 \%$ (19 respondents). An analysis of the literature and empirical research found that CSR is not the dominant criterion in making purchase decisions, so CSR is less important than the other purchase criteria such as price, quality, reliability, customer service, product warranty period, etc. Although consumers make a buying decision based on price, as one of the criteria, it does not mean that the price should be less or equivalent to the price of alternative products, because most of the respondents are willing to pay extra for socially responsible business products (if quality of comparable goods are the same). These results show that consumers really understand the importance of CSR and agree to support it. 
The main reasons, which restrict socially responsible consumption are misconception of consumers, the perception that they have not much power to solve global problems, as well as lack of income, education and information. On the other hand, there are a number of socially responsible consumers in Lithuania, hence products of socially responsible companies have demand and the most important factors in assessing a company's CSR are the efforts to reduce the negative impact on the environment, participation in social problems solving, responsible exploitation of resources, ethical activity. 
